\title{
Le nucléaire, \\ de Montréal à Madrid \\ en passant par Rio...
}

\section{Nuclear energy, from Montreal to Madrid, via Rio}

par Francis SORIN

Rédacteur en chef es articles présentés ici sont une contribution à l'information sur la situation de l'énergie nucléaire en France. Au-delà de nos lecteurs fidèles, nous espérons qu'ils retiendront l'intérêt des responsables des questions énergétiques affrontés, à l'échelle planétaire, à un problème majeur : celui d'un approvisionnement en énergie ajusté aux besoins, sûr et respectueux de l'environnement.

Cet enjeu trace le cadre des discussions organisées par le Conseil Mondial de l'Energie qui tient en ce mois de septembre 1992, à Madrid, son XV $\mathrm{XV}^{*}$ Congrès* ${ }^{*}$ Lors de la précédente manifestation du CME, à Montréal en 1989, les débats avaient fait apparaître l'énergie nucléaire comme un des éléments déterminants de l'approvisionnement énergétique mondial futur. Et cela pour trois raisons essentielles : compétitivité économique, capacité de fournir des quantités massives d'électricité, propreté écologique, dès lors que l'exploitation s'effectue selon les règles appropriées. Cette dernière caractéristique est en soi un atout décisif, dans une période où la nécessité de préserver l'environnement apparaît à juste titre comme un enjeu majeur. Dans certains pays, la contribution du nucléaire à cette sauvegarde est très importante. Dans leur article sur les "Résultats d'exploitation du parc nucléaire français" (publié ci-après) J.-M. Laurent et R. Quéré nous rappellent ainsi, par exemple, que le fonctionnement des centrales nucléaires en France a permis, durant l'année 1991, d'éviter le rejet dans l'environnement de

- 41000 tonnes de poussières:

$-2,3$ millions de tonnes de dioxyde de soufre;

- 0,9 million de tonne de dioxyde d'azote;

- 293 millions de tonnes de gaz carbonique.

On aurait pu penser que lors du récent "Sommet de Rio" cette première "Conférence de la Terre" qui a vu quelque 25000 responsables nationaux et internationaux et "amoureux de la nature" de tous horizons se pencher sur l'avenir de notre cadre de vie - les qualités écologiques de l'énergie nucléaire seraient au moins nettement soulignées. II n'en a rien été. Le recours au nucléaire comme moyen de lutter contre la pollution due à la production d'énergie n'a été évoqué qu'en catimini, avec une discrétion confinant à l'oubli. Ce silence, que l'on peut dire assourdissant, a surpris, voire choqué, en France et ailleurs. Qu'en penseront les experts réunis à Madrid? Répareront-ils l'escamotage de Rio pour faire valoir une nouvelle fois, comme ils l'ont fait à Montréal, que le nucléaire ne mérite pas l'ostracisme dont il est l'objet dans de nombreux pays et instances de la communauté internationale? Réaffirmeront-ils avec clarté que cette forme d'énergie doit être appelée à devenir une des sources principales de l'approvisionnement du monde en électricité ? Après l'oubli de Rio, on écoutera avec un intérêt attentif le message de Madrid.

\footnotetext{
* Le présent numéro - bilingue - de la RGN a été préparé dans l'optique de ce Congrès de Madrid, où il devait être largement diffusé.
}

he articles here provide details on the situation of nuclear energy in France. Apart from our regular readers, we hope to arouse the interest of all those concerned by a major problem, from a planetary scale, namely: the adequate, safe and environment-respecting supply of energy.

The World Energy Council is holding its XV Congress ${ }^{\star}$ this year, September 1992, in Madrid, to continue debate on the subject. During the last meeting of the WEC in Montreal, in 1989, nuclear energy was assumed to be one of the determining factors in future world energy supply. There are three principle reasons for this: competitive price, the capacity to provide massive quantities of electricity, ecological cleanness, so long as producers respect the rules. The latter point is in itself a decisive advantage, in a time when environmental protection is an all-important matter. Certain countries play a considerable role in this nuclear safeguard. In the article "French nuclear power plants operating results", (published in this edition) by J.-M. Laurent and R. Quéré, we are reminded that, for example, operation of nuclear plants in France, in 1991 alone, avoided release into the environment of:

- 41,000 tons of dust;

- 2.3 million tons of sulfur dioxide;

-0.9 million ton of nitrogen dioxide;

- 293 million tons of carbon dioxide.

One might have assumed that during the recent "Rio Summit", the first "Earth Conference", attended by 25,000 national and international delegates and "nature lovers" of all categories, our future lifestyle would be debated - the ecological qualities in nuclear energy would be clearly emphasized. But not at all, use of nuclear power, as a means to fight against pollution caused by energy production, was hardly mentioned, a discretion that sweeps it under the carpet. In France and elsewhere, this shattering silence surprised, even shocked. What will the experts gathered in Madrid think? Will they make good the damage done by the skirmishing of Rio, as they did in Montreal? Will they prove that nuclear energy does not warrant the ostracism demonstrated by so many countries and international authorities? Will they clearly affirm that nuclear energy should be one of the main sources of world electricity supply? After the omission of Rio, the message from Madrid will be listened to with attention. 